2. To: (Receiving Organization)

Distribution

5. Proj./Prog./Dept./Div.:

Spent Nuclear Fuel Project

8. Originator Remarks:

For approval and release.

11. Receiver Remarks:

11A. Design Baseline Document? [ ] Yes [x] No
3. From: (Originating Organization)

Nuclear Safety

6. Design Authority/ Design Agent/Cog. Engr.:

S.D. Kopelic
4. Related EDT No:

N/A

7. Purchase Order No.:

N/A

9. Equip./Component No.:

N/A

10. Systom/Bldg./Facility:

SNF Facilities

12. Major Assm. Dwg. No.:

N/A

13. Permit/Permit Application No:

N/A

14. Required Response Date:

$\mathrm{N} / \mathrm{A}$

\begin{tabular}{|c|c|c|c|c|c|c|c|c|}
\hline 15. & & DAT & NSM & & (F) & (G) & (H) & (I) \\
\hline $\begin{array}{c}\text { (A) } \\
\text { Item } \\
\text { No. }\end{array}$ & (B) Docurnent/Drawing No. & $\begin{array}{l}\text { (C) } \\
\text { Sheet } \\
\text { No. }\end{array}$ & $\begin{array}{l}\text { (D) } \\
\text { Rev. } \\
\text { No. }\end{array}$ & (E) Title or Description of Data Transmitted & $\begin{array}{l}\text { Approval } \\
\text { Desig. } \\
\text { nator }\end{array}$ & $\begin{array}{c}\text { Reason } \\
\text { for Trans- } \\
\text { mittal }\end{array}$ & $\begin{array}{l}\text { Origi- } \\
\text { nator } \\
\text { Dispo- } \\
\text { sition }\end{array}$ & $\begin{array}{l}\text { Receiv- } \\
\text { er } \\
\text { Dispo- } \\
\text { sition }\end{array}$ \\
\hline 1 & $\begin{array}{r}\mathrm{HNF}-3518 \\
\end{array}$ & & 0 & $\begin{array}{l}\text { K Basins Floor Sludge } \\
\text { Retrieval System Knockout Pot } \\
\text { Basket Fuel Bum Accident }\end{array}$ & $\mathrm{N} / \mathrm{A}$ & 1,2 & 1 & 1 \\
\hline & & & & & & & & \\
\hline & & & & & & & & \\
\hline & & & & & & & & \\
\hline & & & & & & & & \\
\hline
\end{tabular}

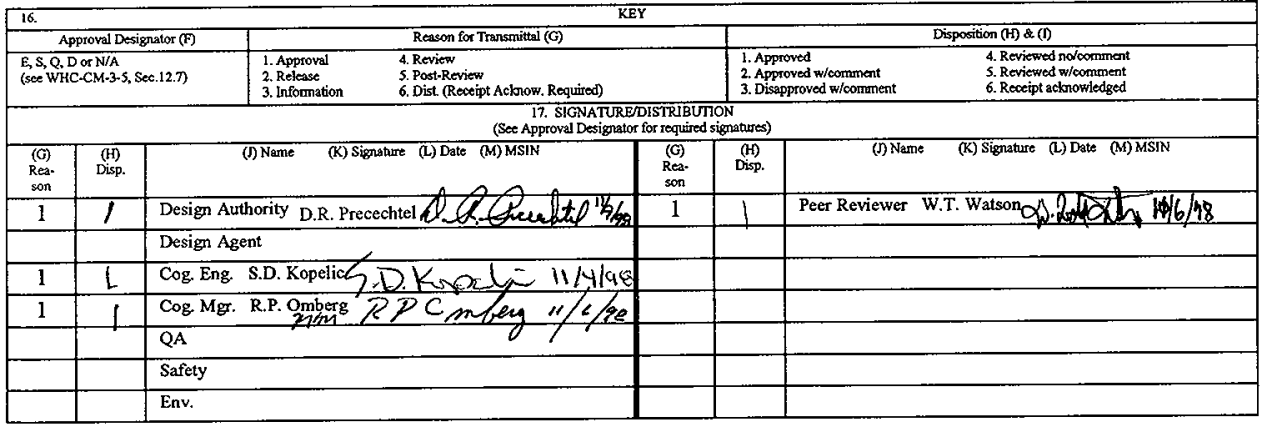

\begin{tabular}{|c|c|c|c|c|}
\hline S.D. Kopelic & $\frac{11-4-9 S}{\text { Date }}$ & R.P.Omberg & $\sum_{\text {Design Authority }}^{20 .} P_{\text {Cognizant Manteg }}^{\text {R.P.Onbers }}$ & $\begin{array}{l}\text { 21. DOE APPROVAL (if required) } \\
\text { Ctri. No. } \\
\text { [] Approved } \\
\text { [] Approved w/comments } \\
\text { [] Disapproved w/comments }\end{array}$ \\
\hline
\end{tabular}




\title{
$S$
}

\section{K Basins Floor Sludge Retrieval System Knockout Pot Basket Fuel Burn Accident}

\author{
R.P. Omberg, S.D. Kopelic * \\ DE\&S Hanford, Richland, WA 99352 \\ U.S. Department of Energy Contract DE-AC06-96RL13200
}

EDT: 624291

UC: 620

Org Code: 2F200

B\&R Code: EW31354040

Charge Code: 105350/CB80

Total Pages: 13

Key Words: K Basin, SAR, Sludge Retrieval System

Abstract: The K Basins Sludge Retrieval System Preliminary Hazard Analysis Report (HNF-2676) identified and categorized a series of potential accidents associated with $\mathrm{K}$ Basins Sludge Retrieval System design and operation. The fuel burn accident was of concern with respect to the potential release of contamination resulting from a runaway chemical reaction of the uranium fuel in a knockout pot basket suspended in the air. The unmitigated radiological dose to an offsite receptor form this fuel burn accident is calculated to be much less than the offsite risk evaluation guidelines for anticipated events. However, because of potential radiation exposure to the facility worker, this accident is precluded with a safety significant lifting device that will prevent the monorail hoist from lifting the knockout pot basket out of the $\mathrm{K}$ Basin water pool.

* XWEST Group, Inc.

TRADEMARK DISCLAIMER. Reference herein to any specific commercial product, process, or service by trade name, trademark, manufacturer, or otherwise, does not necessarily constitute or imply its endorsement, recommendation, or favoring by the United States Government or any agency thereof or its contractors or subcontractors.

Printed in the United States of America. To obtain copies of this document, contact: Document Control Services, P.O. Box 950, Mailstop H6-08, Richland WA 99352, Phone (509) 372-2420; Fax (509) 376-4989.
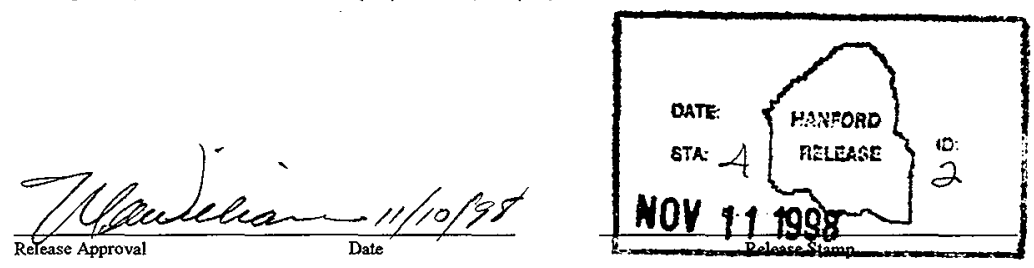

\section{Approved for Public Release}




\title{
K BASINS FLOOR SLUDGE RETRIEVAL SYSTEM KNOCKOUT POT BASKET \\ FUEL BURN ACCIDENT
}

\author{
HNF-3518 \\ Revision 0
}

Steven D. Kopelic

November 1998 


\section{CONTENTS}

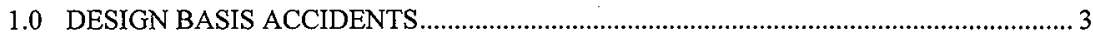

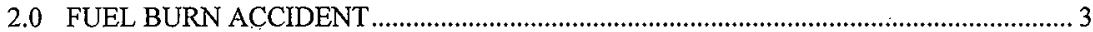

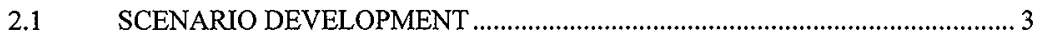

$2.2 \quad$ SOURCE TERM ANALYSIS ........................................................................ 5

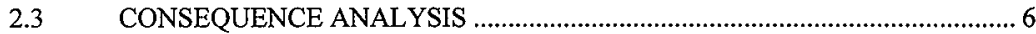

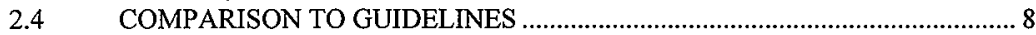

2.5 SUMMARY OF SAFETY-CLASS STRUCTURES, SYSTEMS, AND COMPONENTS AND TECHNICAL SAFETY REQUIREMENT CONTROLS ..................................................................... 9

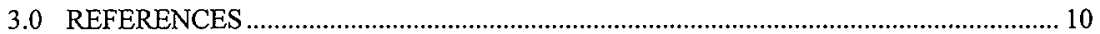

\section{LIST OF TABLES}

Table 1. Air Transport Factors and Resultant Doses for Various Receptors. ............................... 7

Table 2. Radiological Evaluation Guidelines and Limits................................................................. 8

Table 3. Summary of Safety Features Required to Prevent a Fuel Burn Accident........................ 9

\section{LIST OF FIGURES}

Figure 1. Sequence of Events for Development of a Fuel Burn Accident at the K Basin Sludge Retrieval System 
HNF-3518 REV 0

\section{K BASINS FLOOR SLUDGE RETRIEVAL SYSTEM \\ KNOCKOUT POT BASKET \\ FUEL BURN ACCIDENT}

\subsection{DESIGN BASIS ACCIDENTS}

According to DOE Order 5480.23, Nuclear Safety Analysis Reports, design basis accidents are those accidents that are postulated for the purpose of establishing functional requirements for safety structures, systems, and components and equipment. Representative accidents involving the floor sludge retrieval system are discussed in this document. Accidents have been chosen based on the floor sludge retrieval system preliminary hazard analysis (Crowe et al. 1998).

\subsection{FUEL BURN ACCIDENT}

\subsection{SCENARIO DEVELOPMENT}

HNF-2676, K Basins Sludge Retrieval System Preliminary Hazard Analysis Report (Crowe et al. 1998), identified and categorized a series of potential accidents associated with design and operation of the $\mathrm{K}$ Basins floor sludge retrieval system. All hazardous conditions whose unmitigated consequences were assessed as having offsite consequences (S3) or collocated worker consequences ( $\mathrm{S} 2$ ) were chosen for consideration for representative accident selection through a ranking of relative risk. Four entries from the preliminary hazard analysis checklist (Crowe et al. 1998, Table 3-3) represent three accidents with sufficiently high risk rankings to require further evaluation. Those accidents are identified in Table 3-4 of HNF-2676 (Crowe et al. 1998) and summarized below.

- Checklist entry F-05 represents potential damage to the knockout pot strainer basket or to canister because of impact with walls, racks or canisters while a loaded basket is being transported by monorail. Such an event could result in reconfiguration of fuel pieces to the extent that nuclear criticality is a concern. This issue is addressed in HNF-3486, Criticality Analysis of the K Basin Sludge Retrieval System Knockout Pots and Piping (Erickson 1998), and is not discussed further in this document. 
- Checklist entry R-01 represents the potential loss of basin water because of a seismic event that is sufficiently damaging to the basin structure to result in a leak that drains the basin. This issue is addressed in WHC-SD-WM-SAR-062, $K$ Basin Safety Analysis Report (DESH 1998), and is not discussed further in this document.

- Checklist entries $\mathrm{N}-01$ and $\mathrm{N}-03$ a represent the potential for lifting a knockout pot strainer basket loaded with fuel pieces out of the basin water pool. The consequences of this accident, as identified in the hazard analysis, are increased radiation exposure to facility workers and a possible fuel burn (Crowe et al. 1998). This accident is evaluated in this document to determine potential impacts of the accident on onsite and offsite receptors.

The fuel burn accident involves a knockout pot strainer basket filled with pieces of metallic fuel that have been vacuumed up from the basin floor. The general sequence of events leading to a fuel burn event is shown in Figure 1. The sequence starts by recognizing that a knockout pot strainer basket is filled with sludge and has to be emptied. To empty the knockout pot strainer basket, the knockout pot lid is opened and the monorail hoist and basket changeout tool are connected to the knockout pot basket. The hoist is actuated, and because of either operator error or a malfunction of the hoist control mechanism, the hoist lifts the knockout pot strainer basket higher than it is supposed to be lifted. The operator could recognize that the knockout pot strainer basket is higher than it should be and take corrective action, but it is assumed that the knockout pot strainer basket is lifted above the basin water into the air. The knockout pot strainer basket quickly drains and no longer contains the water medium to transfer decay heat from the fuel pieces.

The sludge on the $\mathrm{K}$ Basins floors consists of other materials in addition to fuel. The potential for a fuel burn event depends on the amount and condition of the fuel that resides in the knockout pot strainer basket when it is inadvertently lifted out of the water. If none of the material is fuel, there is no potential for a fuel burn event. Assuming that the knockout pot strainer basket is completely filled with metallic fuel pieces, the combination of ambient air conditions, decay heat generation, heat of reaction from the chemical reaction of the fuel with residual water and/or oxygen in the ambient air, heat of reaction of uranium hydrides, and heat removal by air convection would have to result in a thermal transient in the fuel that could elevate the fuel temperature to the ignition temperature. Upon reaching the ignition temperature, the fuel in the knockout pot strainer basket is hypothesized to continue reacting and releasing fuel oxide particulate matter to the ambient air.

The floor sludge retrieval system vacuum head assembly is designed with a screen-like grid, with a grid size of $0.75 \mathrm{in}$., to prevent picking up pieces of material larger than $0.75 \mathrm{in}$. in diameter. The knockout pot baskets are replete with 0.25 -in.-diameter holes. Because of the high flow rate through the knockout pot strainer baskets, small particles (which are characteristic of the bulk of the sludge) will not be held up in the baskets, so the material retained in the baskets will be in the range of 0.25 in. to 0.75 in. The exact composition of the sludge that will 
be handled by the floor sludge retrieval system is not known; therefore, for this analysis, it is assumed that there are enough pieces of fuel in the appropriate size range to fill a knockout pot strainer basket.

The knockout pot strainer baskets have an inside diameter of $17.3 \mathrm{~cm}$ and an inside height of $69.7 \mathrm{~cm}$, which defines an inside volume of $0.016 \mathrm{~m}^{3}$ per basket. Assuming a fuel metal density of $18,950 \mathrm{~kg} / \mathrm{m}^{3}$ and a packing fraction of 0.5 , the radionuclide inventory of one knockout pot strainer basket is $155 \mathrm{~kg}$ of uranium. This is the material at risk for this accident. For the purpose of this analysis, the fuel pieces are assumed to be maximum burnup Mark IV fuel (Pajunen et al. 1997), which will be a conservative factor in estimating the dose to receptors. The bounding doses to various receptors for this accident are determined below. The magnitude of the radioactive release and subsequent dose associated with this category of accidents are a function of the fuel loading of the basket at the time of the event.

\subsection{SOURCE TERM ANALYSIS}

Section 4.2.1.1.3, pages 4 through 21, of DOE-HDBK-3010-94, Airborne Release Fractions/Rates and Respirable Fractions/Rates for Nonreactor Nuclear Facilities

(Mishima 1994), documents airborne release fractions and respirable fractions from experiments involving self-sustained oxidation above the ignition temperature of plutonium metal in various atmospheres. The experiments were performed on right cylinders (approximately $0.6 \mathrm{~cm}$ in diameter by $1.8 \mathrm{~cm}$ long) of unalloyed plutonium metal that were heated to the ignition temperature in flowing air (Mishima 1994). Pieces of metal this same size could be drawn into the floor sludge retrieval system and captured in the knockout pot strainer basket. The temperature required to reach a sustained metal oxidation condition (i.e., the ignition temperature) for unalloyed plutonium ranged from $490^{\circ} \mathrm{C}$ to $500^{\circ} \mathrm{C}$. The report noted that for plutonium metal pieces in the range of $45 \mathrm{~g}$ to $1,770 \mathrm{~g}$, the metal specimens had to be placed within a ring made of insulating material and placed upon a sheet of insulating material because heat transfer from the metal test enclosure prevented sustained reaction. The airborne release fractions measured in the experiments did not appear to be strongly influenced by any measured parameter such as temperature or air velocity. Based on the data reported in DOE-HDBK-3010-94 (Mishima 1998) for the conditions identified above, the bounding airborne release fraction is assessed to be $5.0 \times 10^{-4}$ and the bounding respirable fraction is 0.5 .

Fuel in the knockout pot basket would have to reach to its ignition temperature before a hypothetical radioactive release could occur. As stated above, the ignition temperature of unalloyed plutonium metal is approximately $500^{\circ} \mathrm{C}$. The fuel at the $\mathrm{K}$ Basins, however, is a mixture of predominately uranium with plutonium, so the ignition temperature could be different than $500^{\circ} \mathrm{C}$. Section 4.2.1.2 of DOE-HDBK-3010-94, page 4-35 (Mishima 1994) states, "Unlike plutonium, uranium is difficult to ignite. The presence of an adherent, protective layer of hyperstoichiometric dioxide at the interface limits oxygen availability. Also the heats of reaction are lower." Therefore, the use of $500^{\circ} \mathrm{C}$ for ignition temperature of the $\mathrm{K}$ Basins spent nuclear fuel is conservative. The experiments in DOE-HDBK-3010-94 (Mishima 1994) cited in 
the paragraph above indicate that it is difficult to ignite specimens the size of those that would be in the knockout pot. However, it is possible that smaller fuel pieces have been captured in the strainer basket, and that the reactive surface area on the fuel fragments is larger than that associated with the experiments. Therefore, the fuel ignition event is assumed to occur, and the doses to onsite and offsite receptors are calculated below.

The amount of respirable material released from the knockout pot strainer basket during the fuel burn event is calculated using the following formula:

$$
\mathrm{Q}=(\mathrm{MAR})(\mathrm{DR})(\mathrm{ARF})(\mathrm{RF})(\mathrm{LPF})
$$

where

MAR $=$ material at risk $(155.0 \mathrm{~kg})$

$\mathrm{DR}=$ damage ratio (conservatively set to 1.0 )

$\mathrm{ARF}=$ airborne release fraction $\left(5.0 \times 10^{-4}\right)$

$\mathrm{RF}=$ airborne release fraction respirable fraction $(0.5)$

$\mathrm{LPF}=$ leak path factor (conservatively set to 1.0 ).

For this event, the amount of respirable radionuclide material released is

$$
\begin{aligned}
\mathrm{Q} & =(155.0 \mathrm{~kg})(1,000 \mathrm{~g} / \mathrm{kg})(1.0)\left(5.0 \times 10^{-4}\right)(0.5)(1.0) \\
& =39 \mathrm{~g} .
\end{aligned}
$$

\subsection{CONSEQUENCE ANALYSIS}

The radiological dose (effective dose equivalent) to a receptor is calculated using the following equation:

where

$$
\mathrm{EDE}=(\mathrm{Q})\left(\frac{\chi}{\mathrm{Q}^{\prime}}\right)(\mathrm{BR})(\mathrm{UD})
$$

$\mathrm{EDE}=$ the effective dose equivalent (rem)

$\mathrm{Q}=$ the respirable quantity released into the air $(\mathrm{g})$

$\chi / \mathrm{Q}^{\prime}=$ the air transport factor $\left(\mathrm{s} / \mathrm{m}^{3}\right.$ [see Table 1 below])

$\mathrm{BR}=$ the average inhalation rate during the release $\left(\mathrm{m}^{3} / \mathrm{s}\right)$

$\mathrm{UD}=$ the committed effective dose equivalent per unit gram inhaled. 
The air transport factors are based on a 1- to 2-hour release from the $\mathrm{K}$ West reactor and adjacent buildings to the onsite and offsite receptors. The 1- to 2-hour duration is based on the duration of fuel burn experiments, ranging from 74 minutes to 155 minutes, cited in DOE-HDBK-3010-94 (Mishima 1994). The air transport factors and subsequent dose consequences for all receptors are shown in Table 1 below.

Table 1. Air Transport Factors and Resultant Doses for Various Receptors.

\begin{tabular}{|l|c|c|c|}
\hline \multicolumn{1}{|c|}{ Receptor type } & Receptor location & $\begin{array}{c}\text { One- to two-hour air } \\
\text { transport factor }\end{array}$ & $\begin{array}{c}\text { Receptor dose } \\
\text { rem (Sv) }\end{array}$ \\
\hline Onsite worker & $100 \mathrm{~m}$ East & $1.24 \mathrm{E}-02$ & $70(0.70)$ \\
\hline Columbia River & $480 \mathrm{~m}$ West & $5.55 \mathrm{E}-04$ & $3.1(0.031)$ \\
\hline Hanford Site boundary & $12,040 \mathrm{~m}$ West & $2.60 \mathrm{E}-05$ & $0.15(0.0015)$ \\
\hline
\end{tabular}

Radiological inhalation dose consequences for these accident conditions are analyzed based on the following assumptions.

- Breathing rate - The light activity breathing rate is $3.33 \times 10^{-4} \mathrm{~m}^{3} / \mathrm{s}$ and is used for all receptors, as specified in HNF-SD-SNF-TI-059, A Discussion on the Methodology for Calculating Radiological and Toxicological Consequences for the Spent Nuclear Fuel Project at the Hanford Site (Rittmann 1998).

- Dose conversion factor - The dose per unit of respirable material inhaled is $4.38 \times 10^{5} \mathrm{rem} / \mathrm{g}$ of fuel, as specified in HNF-SD-SNF-TI-059 (Rittmann 1998). All the material released from the building is treated as respirable (i.e., less than 10- $\mu \mathrm{m}$ aerodynamic diameter).

For all receptors, the duration of exposure is taken to be 2 hours.

Using the respirable radionuclide release quantities calculated in Section 3.4.2.1.2 and the air transport factors specified above, the dose to the offsite receptor is calculated as follows:

$$
\begin{aligned}
\mathrm{EDE}_{\text {offsite }} & =(39 \mathrm{~g})\left(2.60 \times 10^{-5} \mathrm{~s} / \mathrm{m}^{3}\right)\left(3.33 \times 10^{-4} \mathrm{~m}^{3} / \mathrm{s}\right)\left(4.38 \times 10^{5} \mathrm{rem} / \mathrm{g}\right) \\
& =0.15 \mathrm{rem}\left(1.5 \times 10^{-3} \mathrm{~Sv}\right) .
\end{aligned}
$$

The resultant doses for various receptors are summarized in Table 1. 
HNF-3518 REV 0

\subsection{COMPARISON TO GUIDELINES}

The U.S. Department of Energy-recommended radiological risk evaluation guidelines (Sellers 1997) are shown in Table 2.

Table 2. Radiological Evaluation Guidelines and Limits.

\begin{tabular}{|l|c|c|c|}
\hline \multicolumn{1}{|c|}{ Event category } & $\begin{array}{c}\text { Frequency range } \\
\text { (per year) }\end{array}$ & $\begin{array}{c}\text { Onsite risk } \\
\text { evaluation } \\
\text { guidelines* } \\
\text { rem (Sv) }\end{array}$ & $\begin{array}{c}\text { Offsite accident } \\
\text { release limits* } \\
\text { rem (Sv) }\end{array}$ \\
\hline Anticipated & $1.0 \mathrm{E}-01$ to $1.0 \mathrm{E}-02$ & $1(0.01)$ & $0.5(0.005)$ \\
\hline Unlikely & $1.0 \mathrm{E}-02$ to $1.0 \mathrm{E}-04$ & $10(0.1)$ & $5.0(0.05)$ \\
\hline Extremely unlikely & $1.0 \mathrm{E}-04$ to $1.0 \mathrm{E}-06$ & $25(0.25)$ & $5.0(0.05)$ \\
\hline
\end{tabular}

Note: All doses committed effective dose equivalent.

*This terminology is consistent with Tables 1 and 2 of Sellers, E. D., 1997, Risk Evaluation Guidelines (REGs) to Ensure Inherently Safer Designs (Letter 97-SFD-172 to H. J. Hatch, Fluor Daniel Hanford, Incorporated, August 26), U.S. Department of Energy, Richland Operations Office, Richland, Washington.

The vast majority of the several cubic meters of sludge in the $\mathrm{K}$ Basins has been identified as particulate matter that is much smaller than $0.25 \mathrm{in}$. in diameter. The inside volume of a knockout pot strainer basket is approximately $0.016 \mathrm{~m}^{3}$; assuming a packing fraction of 0.5 for pieces contained in the knockout pot strainer basket, a knockout pot strainer basket will hold about $0.008 \mathrm{~m}^{3}$ of fuel. Estimating that metallic fuel pieces ranging in size from $0.25 \mathrm{in}$. to $0.75 \mathrm{in}$. in diameter make up about $0.5 \mathrm{~m}^{3}$ of the sludge in the $\mathrm{K}$ Basins means that the knockout pot strainer baskets would be filled about 63 times $\left(0.5 \mathrm{~m}^{3} / 0.008 \mathrm{~m}^{3}=63\right)$. This estimate could be improved with further research into sludge volume and composition and could be expected to be much lower.

The annual frequency of lifting a knockout pot strainer basket out of the water pool at $\mathrm{K}$ Basins is estimated by using the frequencies for (1) moving a full knockout pot strainer basket with the monorail hoist, (2) operator error in failing to stop the upward vertical motion at the correct vertical position of the knockout pot strainer basket and (3) failure of the monorail hoist control device such that the operator is unable to stop the upward movement of the knockout pot strainer basket. The frequency of this event will be assumed to place it into the "anticipated" category.

The unmitigated radiological dose to the offsite receptor from this fuel burn accident is calculated to be much less than the offsite risk evaluation guidelines for anticipated events (see Tables 1 and 2). Therefore, features applied to the floor sludge retrieval system to prevent or mitigate the effects of this fuel burn accident are not required to be safety class. The fuel burn 
accident is prevented by specially designed hardware that precludes lifting the knockout pot strainer basket out of the $\mathrm{K}$ Basin water pool. This hardware consists of a knockout pot basket changeout tool between the hoist and the knockout pot strainer basket that physically prevents the hoist from lifting the knockout pot strainer basket above the pool water level. This changeout tool is designated safety significant because of the tool's function to avoid dose consequences in excess of onsite guidelines and excessive radiation exposure to the facility workers.

\subsection{SUMMARY OF SAFETY-CLASS STRUCTURES, SYSTEMS, AND COMPONENTS AND TECHNICAL SAFETY REQUIREMENT CONTROLS}

The safety-significant equipment designated to prevent the dose consequences of the bounding knockout pot strainer basket fuel burn accident is the knockout pot basket changeout tool.

The safety-significant function of the knockout pot basket changeout tool for the fuel burn accident is to create a physical situation that makes it impossible for any operation of the monorail hoist to lift a knockout pot strainer basket above the level of water that exists in the $\mathrm{K}$ Basin pool when a full knockout pot strainer basket could be moved by the monorail hoist.

The accident identified in the preliminary hazard analysis report (Crowe et al. 1998) that may potentially lead to a fuel burn accident release is shown in Table 3 along with corresponding checklist designators, safety functions, and safety structures, systems, and components. The radiological dose consequences of this accident are bounded by the fuel burn accident as analyzed in previous sections.

Table 3. Summary of Safety Features Required to Prevent a Fuel Burn Accident.

\begin{tabular}{|l|l|l|l|}
\hline \multicolumn{1}{|c|}{ Candidate accident } & $\begin{array}{c}\text { Checklist } \\
\text { designator* }\end{array}$ & \multicolumn{1}{|c|}{ Safety function } & \multicolumn{1}{c|}{ Safety features } \\
\hline $\begin{array}{l}\text { Fuel burn due to a } \\
\text { knockout pot strainer } \\
\text { basket being lifted above } \\
\text { the surface of the K Basin } \\
\text { water pool and exposed to } \\
\text { the air }\end{array}$ & $\mathrm{N}-01$ & $\begin{array}{l}\text { Prevent the monorail } \\
\text { hoist from lifting the } \\
\text { knockout pot basket } \\
\text { out of the basin water } \\
\text { pool }\end{array}$ & $\begin{array}{l}\text { Safety-significant } \\
\text { equipment: } \\
\text { Specially designed } \\
\text { fixture that goes } \\
\text { between the hoist and } \\
\text { the knockout pot basket }\end{array}$ \\
\hline
\end{tabular}

* Checklist designators are from Crowe, R. D., D. E. Krahn, and S. D. Kopelic, K Basins Sludge Retrieval System Preliminary Hazard Analysis Report, HNF-2676, Rev. 0, Fluor Daniel Hanford, Incorporated, Richland, Washington. 


\subsection{REFERENCES}

DOE Order 5480.23, 1992, Nuclear Safety Analysis Reports, U.S. Department of Energy, Washington, D.C.

DESH, 1998, $K$ Basin Safety Analysis Report, WHC-SD-WM-SAR-062, Rev. 3F, DE\&S Hanford, Incorporated, for Fluor Daniel Hanford, Incorporated, Richland, Washington.

Crowe, R. D., D. E. Krahn, and S. D. Kopelic, 1998, K Basins Sludge Retrieval System Preliminary Hazard Analysis Report, HNF-2676, Rev. 0, Fluor Daniel Hanford, Incorporated, Richland, Washington.

Erickson, D. G., 1998, Criticality Analysis of the K Basin Sludge Retrieval System Knockout Pots and Piping, HNF-3486, Rev. 0, Draft, Fluor Daniel Hanford, Incorporated, Richland, Washington.

Mishima, J., 1994, Airborne Release Fractions/Rates and Respirable Fractions/Rates for Nonreactor Nuclear Facilities, DOE-HDBK-3010-94, U.S. Department of Energy, Washington, D.C.

Pajunen, A. L., L. D. Muhlestein, and M. R. Allen, 1997, Particulate Inventory of a Multi-Canister Overpack, HNF-SD-SNF-CN-008, Rev. 0, Fluor Daniel Hanford, Incorporated, Richland, Washington.

Rittmann, P. D., 1998, A Discussion on the Methodology for Calculating Radiological and Toxicological Consequences for the Spent Nuclear Fuel Project at the Hanford Site, HNF-SD-SNF-TI-059, Rev. 1, Fluor Daniel Hanford, Incorporated, Richland, Washington.

Sellers, E. D., 1997, Risk Evaluation Guidelines (REGs) to Ensure Inherently Safer Designs (Letter 97-SFD-172 to H. J. Hatch, Fluor Daniel Hanford, Incorporated, August 26), U.S. Department of Energy, Richland Operations Office, Richland, Washington. 


\section{Figure 1. Sequence of Events for Development of a Fuel Burn Accident at the K Basin Sludge Retrieval System}
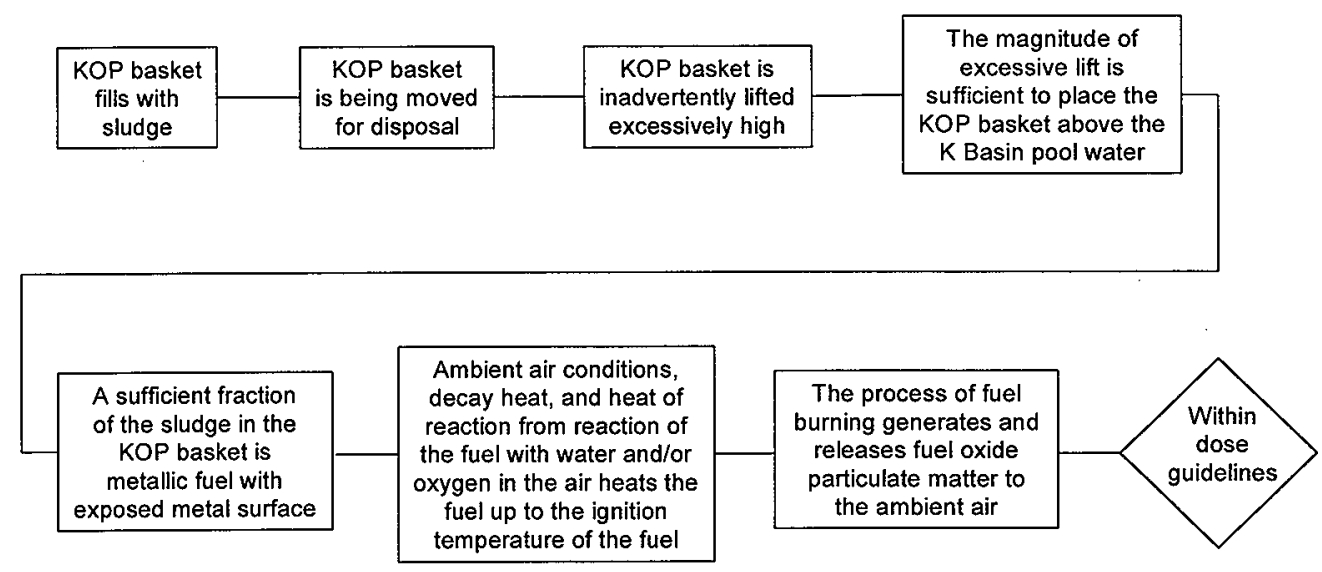

KOP = knockout pot 


\section{CHECKLIST FOR PEER REVIEW}

\section{Document Reviewed: $\quad$ HNF-3518, K Basins Floor Sludge Retrieval System Knockout Pot Basket Fuel Burn Accident}

Scope of Review: Entire document

Yes No NA

[ ] [ ] \} ] ^ { * } \text { Previous reviews complete and cover analysis, up to scope of this review, } with no gaps.

D [] [ ]

凶] [ [ ]

[X] [ ] [ ]

[ ] [ ] $\mathbb{E}$

$\otimes[][]$

X] [ ] []

d] [ ] [ ]

$\mathbb{X}[][]$

$凶[][]$

[ ] [ ]

[ ] [ ] $[x]$

Ex [ ] [ ]

[DA [ ] [ ]

$凶[][]$

¿] [ ] [ ]

[ ] [ ] [X]

[]

Problem completely defined.

Accident scenarios developed in a clear and logical manner.

Necessary assumptions explicitly stated and supported.

Computer codes and data files documented.

Data used in calculations explicitly stated in document.

Data checked for consistency with original source information as applicable.

Mathematical derivations checked including dimensional consistency of results.

Models appropriate and used within range of validity or use outside range of established validity justified.

Hand calculations checked for errors. Spreadsheet results should be treated exactly the same as hand calculations.

Software input correct and consistent with document reviewed.

Software output consistent with input and with results reported in document reviewed.

Limits/criteria/guidelines applied to analysis results are appropriate and referenced. Limits/criteria/guidelines checked against references.

Safety margins consistent with good engineering practices.

Conclusions consistent with analytical results and applicable limits.

Results and conclusions address all points required in the problem statement.

Format consistent with appropriate NRC Regulatory Guide or other standards Review calculations, comments, and/or notes are attached.

\section{4 [ I [ ] Document approved.}

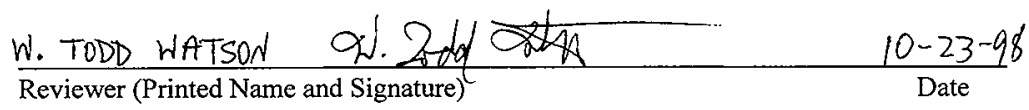

* Any calculations, comments, or notes generated as part of this review should be signed, dated and attached to this checklist. Such material should be labeled and recorded in such a manner as to be intelligible to a technically qualified third party. 
DISTRIBUTION SHEET

\begin{tabular}{|c|c|c|c|c|c|}
\hline \multirow{2}{*}{$\begin{array}{l}\text { To } \\
\text { Distribution }\end{array}$} & \multirow{2}{*}{\multicolumn{3}{|c|}{$\begin{array}{l}\text { From } \\
\text { Nuclear Safety }\end{array}$}} & \multicolumn{2}{|l|}{ Page 1 of 1} \\
\hline & & & & \multicolumn{2}{|l|}{ Date 11/9/98 } \\
\hline \multicolumn{4}{|c|}{ Project Title/Work Order } & \multicolumn{2}{|c|}{ EDT No. 624291} \\
\hline \multicolumn{4}{|c|}{$\begin{array}{l}\text { HNF- } 3518 \text {, Rev. } 0 \\
\text { K Basins Floor Sludge Retrieval System Knockout Pot Basket Fuel Burn } \\
\text { Accident }\end{array}$} & \multicolumn{2}{|l|}{ ECN No. N/A } \\
\hline Name & MSIN & $\begin{array}{c}\text { Text } \\
\text { With All } \\
\text { Attach. }\end{array}$ & Text Only & $\begin{array}{l}\text { Attach./ } \\
\text { Appendix } \\
\text { Only }\end{array}$ & $\begin{array}{c}\text { EDT/ECN } \\
\text { Only }\end{array}$ \\
\hline L. J. Garvin & R3-26 & $\mathrm{X}$ & & & \\
\hline S. B. Harrington & R3-26 & $\mathrm{x}$ & & & \\
\hline J.L. Julyk & $X 3-85$ & $\mathrm{X}$ & & & \\
\hline M.A. Medsker & $\mathrm{R} 3-26$ & $\mathrm{X}$ & & & \\
\hline R. H. Meichle & $\times 3-79$ & $\mathrm{x}$ & & & \\
\hline S.D. Kopelic & R3-26 & $\mathrm{x}$ & & & \\
\hline R. P. Omberg & R3-26 & $\mathrm{x}$ & & & \\
\hline S.H. Peck & $\mathrm{X} 3-85$ & $x$ & & & . \\
\hline D.R. Precechtel & $X 3-85$ & $x$ & & & \\
\hline L. S. Semmens & $\times 3-85$ & $x$ & & & \\
\hline W. T. Watson & $\mathrm{R} 3-26$ & $\mathrm{x}$ & & & \\
\hline SNF Project Files & R3-11 & $\mathrm{X}$ & & & \\
\hline K Basin Project Files & $X 3-85$ & $\mathrm{X}$ & & & \\
\hline
\end{tabular}

